This is the accepted version of an article published by Wiley in Journal of Agrarian Change Vol. 17 (4)

October 2017, 733-738. Published version available from:

http://onlinelibrary.wiley.com/doi/10.1111/joac.12239/full

Accepted version downloaded from SOAS Research Online: http://eprints.soas.ac.uk/24894/

\title{
Introduction: Land Rights, Restitution, Politics and War in Colombia
}

\section{Christopher Cramer, Department of Development Studies SOAS University of} London

\section{Elisabeth Jean Wood, Department of Political Science, Yale University}

\section{Abstract:}

This article introduces papers in a Symposium that report some of the findings and arguments to emerge from a collaborative research project involving five Colombian universities forming the Observatorio de Restitución y Regulación de Derechos de Propiedad Agraria (Observatory of Restitution and Regulation of Agrarian Property Rights). In a number of ways, the research presented in the Symposium advances understanding of the political economy of rural Colombia, and of war in Colombia, and the papers, drawing on the original evidence collected by Observatorio researchers, develop arguments that have a wider relevance too for agrarian political economy and the understanding of violent conflict. In particular, the papers highlight the direct participation of elites in violent conflict; the varieties and nuances of wartime primitive accumulation; the complexities of the state's role in wartime agrarian political economy; the gender dimensions of agrarian conflict; the interaction of war and law; and the significance for service provision of farm size. As Colombia - hopefully - passes from long war to peace, these arguments and this evidence may be valuable in debates about what kind of peace can develop.

In the three years leading up to the momentous signing in 2016 of a peace accord 
This is the accepted version of an article published by Wiley in Journal of Agrarian Change Vol. 17 (4) October 2017, 733-738. Published version available from:

http://onlinelibrary.wiley.com/doi/10.1111/joac.12239/full

Accepted version downloaded from SOAS Research Online: http://eprints.soas.ac.uk/24894/

between the Colombian government and the FARC (the main insurgent group), researchers from the Observatorio de Restitución y Regulación de Derechos de 
This is the accepted version of an article published by Wiley in Journal of Agrarian Change Vol. 17 (4)

October 2017, 733-738. Published version available from:

http://onlinelibrary.wiley.com/doi/10.1111/joac.12239/full

Accepted version downloaded from SOAS Research Online: http://eprints.soas.ac.uk/24894/

Propiedad Agraria (Observatory of Restitution and Regulation of Agrarian Property Rights) collected new evidence on the dynamics of conflict, political mobilization, and rural economies in Colombia. This symposium presents some of the Observatorio's results. ${ }^{1}$

The theoretical arguments and empirical findings in the symposium papers advance our understanding of the conflict and of rural political economy in Colombia in significant ways. The insights gained are not merely of historical interest for scholars of a war that may hopefully finally be over. More than this, they suggest some of the political, social and economic challenges that citizens and politicians will face in post-war Colombia, if the peace is to last and especially if it is to be more than a peace serving the interests of a narrow elite. They also deepen scholarly understanding of the economic, legal and social legacies of war, as well as the challenges and opportunities those legacies pose for post-conflict societies. Land issues will be at the core of those challenges. As Zetter $(2011,66)$ put it: the 'issue of land both permeates and mediates all the "r" processes - reconstruction, rebuilding peace, return, reintegration'. Meanwhile, the research reported in this symposium has the added benefit of contributing to debates on how most appropriately to analyse and understand the political economy of armed conflict. The contributions here add nuance to some debates for example, on primitive accumulation and on gender and conflict - while also highlighting major gaps in the literature, for instance on the direct participation in large-scale violence of elite actors in the licit economy.

\footnotetext{
${ }^{1}$ The Observatorio is a network of researchers from five Colombian universities, with an international advisory board.
} 
This is the accepted version of an article published by Wiley in Journal of Agrarian Change Vol. 17 (4)

October 2017, 733-738. Published version available from:

http://onlinelibrary.wiley.com/doi/10.1111/joac.12239/full

Accepted version downloaded from SOAS Research Online: http://eprints.soas.ac.uk/24894/

One of the defining features of the Colombian peace process has been that it was Colombians who led and designed the process, the format and content of negotiations, and the substance of the peace accords, though of course there was external assistance (from Cuba and Norway in particular). This may suggest that Colombia cannot be a 'pacified peace' (Berdal and Suhrke, 2012) where an external power imposes its own version of peace, though it would be remiss to ignore the disciplining role of external forces, not least 'the markets', in shaping political incentives. As Peters $(2013,553)$ notes, some argue that neo-liberal globalization has produced the 'most significant reassertion of the primacy of struggles over the global politics of land since the early 1950s'.

It remains of course to be seen what form peace will take after the ratification by Colombia's Congress of the Havana Accords. Will it be a 'Victor's Peace', where despite a negotiated agreement one 'side' will be able to impose its will and agenda without restraint on post-war society? That seems pretty much what former president Álvaro Uribe sought in leading the successful 'no' vote challenge to the original version of the peace deal put to a national plebiscite. ${ }^{2}$ Will it be a Conflictual Peace, as in Afghanistan, where peace is declared but organized armed conflict persists in parts of the country (or in a Colombian version ongoing assassinations of social movement and trade union leaders and the persistence of violence by the 'bacrim', the bandas criminales that sprang up in the wake of paramilitary demobilisation)? The research presented here may

\footnotetext{
2 'No' supporters proposed 410 modifications to the peace agreement signed in Havana between the FARC and President Santos's negotiating team, 'many of them poison darts aimed at the heart of the negotiations' (Ruiz, 2016).
} 
This is the accepted version of an article published by Wiley in Journal of Agrarian Change Vol. 17 (4)

October 2017, 733-738. Published version available from:

http://onlinelibrary.wiley.com/doi/10.1111/joac.12239/full

Accepted version downloaded from SOAS Research Online: http://eprints.soas.ac.uk/24894/

give some clues at least to some of the interests and dynamics likely to shape the peace.

It is very clear, for example, that a sizeable and powerful section of the Colombian elite had a direct stake in the war. Many cattle ranchers, as GutiérrezSanín and Vargas (2017) show, were much more than indirect beneficiaries of the massive displacement of people from their land during the war. Rather, they actively took part in the war, often leading paramilitary groups. Meanwhile, as several of the authors emphasize, there were others who were less directly engaged in armed conflict but who took strong advantage of the forced displacement of people from land, of the ongoing tensions between different state agencies, and of the often obfuscatory character of legal institutions. The resulting increase in Colombia's already very high concentration of land has been a key feature of the war and one whose post-war implications will take years to unfold.

The recent history of post-war land reform and restitution, including notable examples such as South Africa and Zimbabwe, does nothing to suggest a rapid, equitable process of restitution and land reform in post-war Colombia. In fact, restitution has been underway since 2011 in Colombia, and its painfully slow progress and legal culs-de-sac are all too familiar to observers of post-apartheid South Africa (O’Laughlin et al, 2013; Hall, 2014) and post-war Zimbabwe (Rutherford, 2008, 2012). 
This is the accepted version of an article published by Wiley in Journal of Agrarian Change Vol. 17 (4)

October 2017, 733-738. Published version available from:

http://onlinelibrary.wiley.com/doi/10.1111/joac.12239/full

Accepted version downloaded from SOAS Research Online: http://eprints.soas.ac.uk/24894/

An emphasis on women's access to land in Colombia's 2011 restitution law and subsequent regulations has been unable to overcome historically entrenched gender inequalities in much of Colombian society. In contrast, women have come to play a wide variety of roles in the insurgency. While participation in the ranks of the FARC was initially highly gendered, the FARC came to put an uncommon emphasis on the recruitment of women. Gutiérrez-Sanín and Carranza (2017) show that women's roles in the guerrilla shifted over time, from the provision of basic services (cooking, etc.) to taking on new roles including as direct combatants. If this recruitment drive and a shift in the gendered division of wartime labour was partly a response to the organization's decision to expand rapidly, it nonetheless led to an institutionalisation of new gender norms within the FARC.

The article reinforces recent literature that emphasizes the agency of women during war as well as their victimization. To be sure, women are often victims of war, and suffer war and its consequences differently from men: they may be targeted much more frequently with sexual violence than with lethal violence, for example. (Men too suffer sexual violence but less frequently than women in the cases where it has been well documented, with the exception of sexual torture for which men are often the most frequently victimized.) And women often suffer in specific ways the indirect effects of war as well. Plümper and Neumayer (2006) find evidence that war reduces the gender gap in life expectancy between women and men, reflecting a large and lasting indirect burden of war on women that is higher than for men. But there is also increasingly rich evidence (Kriger, 2003; Viterna 2013, Thomas and Bond 2015) 
This is the accepted version of an article published by Wiley in Journal of Agrarian Change Vol. 17 (4)

October 2017, 733-738. Published version available from:

http://onlinelibrary.wiley.com/doi/10.1111/joac.12239/full

Accepted version downloaded from SOAS Research Online: http://eprints.soas.ac.uk/24894/

that women actively and voluntarily participate in wars. They may do so to escape the drudgery and violence of patriarchy in rural areas, because members of their family or other social networks joined before them, or out of conviction. The article by Gutiérrez-Sanín and Carranza (2017) confirms these patterns but adds an analysis of the often-neglected organizational characteristics that led to women's widespread recruitment as combatants.

There is of course a long history of war shaking up the gender division of labour, with war coming to be regarded from the safe distance of historical hindsight as, in gender terms, quite progressive. But there is also a history of peace unravelling the gains in gender equality and reversing the at least partial liberation of women from traditional restricted social roles (Wood 2008). The research findings highlighted here serve notice that there will be a challenge to reinforce, spread and apply in non-military contexts the kind of norms, rhetoric and practice of greater gender equality that the FARC in wartime embraced.

These are examples of the way in which many wars outgrow their original 'root causes'. While these root causes may well continue to influence social relations in wartime, the dynamics of armed conflict - especially in societies such as Colombia that have sustained such a lengthy war - tend to generate new relations, new tensions, new challenges (Woodward, 2007).

Indeed, there is an emerging literature on the social legacies of war, the transformation of actors, social structures, gender relations and social norms at the local level (Wood 2008; Starr and Wood in progress). Those transformations 
This is the accepted version of an article published by Wiley in Journal of Agrarian Change Vol. 17 (4)

October 2017, 733-738. Published version available from:

http://onlinelibrary.wiley.com/doi/10.1111/joac.12239/full

Accepted version downloaded from SOAS Research Online: http://eprints.soas.ac.uk/24894/

vary sharply across civil wars. For example, land holdings in El Salvador were dramatically fragmented by the state's counterinsurgency agrarian reform, occupation of land by insurgent-allied cooperatives, and market transactions driven by remittances from the US and the inability of landlords to work their land (Wood 2003). Although social relations in Guatemala changed to some extent, there was little change in agrarian property during the years of the war. In Peru, the extent to which agrarian social relations were transformed by the war is as yet little analysed (but see Soifer and Vergara, forthcoming).

In sharp contrast, in Colombia agrarian property rights and patterns of de facto land use became more concentrated over the decades of the war. ${ }^{3}$ To our knowledge, Colombia is the only recent conflict in which forcible dispossession for the purpose of immediate transfer (in contrast to 'mere' forced displacement) occurred to such an extent.

The evidence from Colombia presented here (see Peña et. al. 2017; also Vargas and Uribe, 2017) helps to refine the recently revived idea of primitive accumulation. Primitive accumulation and 'accumulation by dispossession' (Harvey, 2009), have been used by a number of political economists and in a variety of ways: to cover the wide wingspan of the advancing commercialization of social life (Harvey, 2009); to suggest a feature common to developing economies but with echoes of the early foundations of capitalism (Khan, 2000); and to highlight a common feature of modern war economies (Cramer, 2006;

\footnotetext{
${ }^{3}$ For example, on the increase in rural land concentration and of the Land Gini in
} Colombia between 2000 and 2009 see Ibáñez (2009). 
This is the accepted version of an article published by Wiley in Journal of Agrarian Change Vol. 17 (4)

October 2017, 733-738. Published version available from:

http://onlinelibrary.wiley.com/doi/10.1111/joac.12239/full

Accepted version downloaded from SOAS Research Online: http://eprints.soas.ac.uk/24894/

Cramer and Richards, 2011), partly to suggest that these wars may have dynamics that in time may be more complex than the simplistic World Bank (2003) notion of war as 'development in reverse'. But what is clear from Colombia is that primitive accumulation - a concept deep in the historical memory of political economy, in Smith's formulation as original accumulation and in Marx - requires greater detail and nuance and comes in varied forms.

In the classic formulation, as for example in the enclosure movement in early modern England, those who dispossess poor people by privately 'enclosing' erstwhile common property deprive people of access to the means of production and force them either into indigence and dependence on charity or into dependence on wage labour. At the same time, the newly accumulated and increasingly concentrated land generates surpluses that form the initial capital that over time becomes the basis for the self-sustaining logic of capitalist expansion: 'extra-economic' coercion enables and is in turn and time displaced by 'economic compulsions'.

The general idea has been invoked - for Colombia and elsewhere - in fairly sweeping terms. In contrast, Peña et al (2017) show that the logic and sequencing of extra-economic and economic compulsions can unfold in different ways. In parts of Colombia - especially in the north - a pretty direct form of primitive accumulation has taken place. But in other areas, there has been a more indirect dynamic. Violence itself was not always the direct basis of accumulation of land and related assets (including access to state credits). Rather, violence intersected with the contradictions of the state (with different 
This is the accepted version of an article published by Wiley in Journal of Agrarian Change Vol. 17 (4)

October 2017, 733-738. Published version available from:

http://onlinelibrary.wiley.com/doi/10.1111/joac.12239/full

Accepted version downloaded from SOAS Research Online: http://eprints.soas.ac.uk/24894/

parts of the state at institutional loggerheads with one another) and inconsistent formal, legal 'rules of the game' to create opportunities that others (those not directly involved in the violence) came to take advantage of, partly based on their connections to state authorities. Indeed, some of those who accumulated land through this indirect mechanism were deprived of their new assets in the land restitution process and have lodged challenges to that process. Drawing on judicial rulings in restitution cases, Peña and her co-authors show how the war weakened the rights of the rural poor, and strengthened the biased adjudication of property rights toward those with personal connections to elites and state officials, in part because of the 'capture' of key local state agencies by local elites and armed actors.

Where the beneficiaries of dispossession were not participants in the violence for example in North Santander where, after demobilisation of paramilitary groups, large palm oil producers acquired lands that had earlier been drained by the paramilitaries - the development policies of the Colombian state drove the dynamic of capitalist expansion built on extra-economic compulsion. But as Vargas and Uribe (2017) show, the state has not acted as a unitary organization, exclusively serving one set of interests.

In the same way, ideas about 'why men rebel' or more broadly what motivates people to participate directly in armed conflicts still need further development. Colombia has already provided detailed evidence (Gutierrez-Sanin, 2004) that challenges the absurdity of the mainstream 'economic perspective' on armed conflict, namely the notion that the poor have a comparative advantage in 
This is the accepted version of an article published by Wiley in Journal of Agrarian Change Vol. 17 (4)

October 2017, 733-738. Published version available from:

http://onlinelibrary.wiley.com/doi/10.1111/joac.12239/full

Accepted version downloaded from SOAS Research Online: http://eprints.soas.ac.uk/24894/

violence and that recruits to violent organizations are people who have rationally chosen collective violence exclusively to maximise their individual utility where there are direct material rewards to participation. Much of this earlier evidence - corroborating evidence from studies elsewhere (including Wood, 2003, on El Salvador or Kriger, 2003 on Zimbabwe) - focused on the complex motivations for participation in collective armed action. But new evidence (Gutiérrez-Sanín and Vargas, 2017) focuses more unusually on elites, often thought to stand aloof from violent conflict and perhaps (Grenier, 1996) to orchestrate though not to get their hands dirty. Colombian evidence shows - to the contrary - that elites do not always shy away from very direct involvement. Their violent utility maximisation may shine through, but it is hardly driven by poverty and the closure of any other options for survival. Where the standard economic model of civil war highlights the key actor of collective violence as a young, poor, unemployed male, Gutiérrez-Sanín and Vargas emphasise how important in Colombia's war 'middle aged, well to do and well connected' men have been, a class of what might be called 'landed bellocrats' and particularly in this paper a group of cattle ranchers.

If some cattle ranching and other elites (including banana growers) participate directly in violent conflict then they represent those with 'passionate interests' (Cramer, 2006) who give the lie to the argument, traced to its historical origins by Hirschman (1977), that engaging in commercial interests deflects people from more extreme, violent behaviour and to the argument that 'development retards 
This is the accepted version of an article published by Wiley in Journal of Agrarian Change Vol. 17 (4)

October 2017, 733-738. Published version available from:

http://onlinelibrary.wiley.com/doi/10.1111/joac.12239/full

Accepted version downloaded from SOAS Research Online: http://eprints.soas.ac.uk/24894/

war' (World Bank, 2003). ${ }^{4}$ This evidence also appears to belie the argument some have made that large landowners in Colombia act as a democratic check on the behaviour of politicians and that they are also associated with the provision of public goods and service delivery.

Paying closer attention to the Colombian evidence on the relative weight of large, small and - significantly - medium size farmers in particular municipalities suggests a very different dynamic of service provision, especially in the wake of moves towards greater local democracy. Velásquez (2017) introduces the highly suggestive results of compositional analysis (going beyond what can be misleading implications of Gini coefficients) of municipal level data on landholding size. The findings upend some claims held about rural Colombia and they do so on the basis of a much-needed step in disaggregating the rural population.

Velásquez's article may point to an area needing further research at local levels. And it touches - as do other articles in the symposium - on the fundamental social and economic challenges of what Ruiz (2016) referred to as a rural society that 'is among the most backward in the world'. Peace is likely to be a fillip to new national and international investment in commercial agri-business. Rather than a polarized debate simply pitting proponents of large-scale agriculture against critics of 'land grabbing' and supporters of a small-scale farming, there

\footnotetext{
${ }^{4}$ As acknowledged in the Bank (IEG, 2016, ix), 'the development community's perception of conflict and violence is no longer primarily associated with low-income countries' since the evidence suggests a higher incidence, lately, of violent conflict in middle income countries than in low income countries.
} 
This is the accepted version of an article published by Wiley in Journal of Agrarian Change Vol. 17 (4)

October 2017, 733-738. Published version available from:

http://onlinelibrary.wiley.com/doi/10.1111/joac.12239/full

Accepted version downloaded from SOAS Research Online: http://eprints.soas.ac.uk/24894/

needs to be more debate including on the consequences for policy, about which relatively large-scale agriculture is potentially progressive, generating

employment (especially of poor rural women) and foreign exchange, while also addressing the need to keep a lid on food price inflation, and which forms of commercial agriculture are less socially useful. Many might argue that the big investment in palm oil referred to in some of the articles here is simply a new form of cattle ranching - enclosing huge swathes of land to generate high profits without creating meaningful employment (and employment on poor terms). These issues will also be especially pressing in areas of the country, typically borderlands, where there will need to be some transition away from illicit crop production, despite the direct and indirect contribution that coca production, processing and trade may have made to local employment.

Thus the research highlighted in this symposium - the role of agrarian elites in violence but not in the provision of public services, the processes by which land concentration occurred, the origins of the FARC's high proportion of female combatants, and the failure of restitution policies to adequately address the gendered dynamics of war and patriarchy - contributes to the analysis of the many striking challenges that Colombia now faces. Of course there are other important legacies of war (Wood 2008) that are not addressed here, including widespread displacement, the limited reach of the state into formerly conflicted regions, the wartime weakening of fiscal links between rural Colombia and the state, the threat of political entrepreneurs emerging who try to hold onto their wartime claims to violence rights (Cramer, 2015) and who may hope to trade acquiescence to peace for licences or pay-offs in a version of what de Waal 
This is the accepted version of an article published by Wiley in Journal of Agrarian Change Vol. 17 (4)

October 2017, 733-738. Published version available from:

http://onlinelibrary.wiley.com/doi/10.1111/joac.12239/full

Accepted version downloaded from SOAS Research Online: http://eprints.soas.ac.uk/24894/

(2015) calls a 'payroll peace', among others. We hope it is evident that the

Observatorio's research also contributes more broadly to ongoing scholarly

debates on the politics and political economy of war and of agrarian change.

\section{References:}

Berdal, M. and Suhrke, A. (2012). The peace in between: post-war violence and peacebuilding. London: Routledge.

Cramer, C. (2006). Civil war is not a stupid thing: accounting for violence in developing countries. London: C. Hurst.

Cramer, C. (2015), 'Peace work: labour markets, work and violence', Human

Development Report Office, New York: UNDP.

Cramer, C. and Richards, P. (2011). Violence and War in Agrarian Perspective. Journal of Agrarian Change, 11 (3), 277-97.

De Waal, A. (2015). The real politics of the horn of Africa: money, war and the business of power. London: Polity.

Grenier Y. (1996). From causes to causers: the etiology of Salvadoran internal war revisited. Journal of Conflict Studies (Fall): 26-43. 
This is the accepted version of an article published by Wiley in Journal of Agrarian Change Vol. 17 (4)

October 2017, 733-738. Published version available from:

http://onlinelibrary.wiley.com/doi/10.1111/joac.12239/full

Accepted version downloaded from SOAS Research Online: http://eprints.soas.ac.uk/24894/

Gutiérrez-Sanín F. (2004). Criminal rebels? A discussion of civil war and

criminality from the Colombian experience. Politics and Society 32 (2), 257-285.

Gutiérrez-Sanín, F. and Vargas, J. (2017). Elite participation in civil war. Journal of Agrarian Change, Symposium on Land Rights, Restitution, War and Peace in Colombia

Gutiérrez-Sanin, F. and Carranza, F. (2017). Organising women for combat: the experience of the FARC in the Colombian war. Journal of Agrarian Change, Symposium on Land Rights, Restitution, War and Peace in Colombia

Hall, R. (2014). Who, what, where, how, why? the many disagreements about land redistribution in South Africa, In Walker, C. and Cousins, B. (eds.). Land divided: Land reform in South Africa for the 21st century. South Africa: Jacana Media, 127-144.

Harvey, D. (2009). The "New" Imperialism: accumulation by dispossession. Socialist Register, Vol.40, 63-87.

Hirschman, A.O. (1977). The passions and the interests: political arguments for capitalism before its triumph. Princeton: Princeton University Press.

Ibáñez, A.M. (2009). Concentration of rural property in Colombia. Policy Brief 5/2009, Oslo: PRIO.

IEG (2016). World Bank Group engagement in situations of fragility, conflict and violence. Washington: World Bank Group. 
This is the accepted version of an article published by Wiley in Journal of Agrarian Change Vol. 17 (4)

October 2017, 733-738. Published version available from:

http://onlinelibrary.wiley.com/doi/10.1111/joac.12239/full

Accepted version downloaded from SOAS Research Online: http://eprints.soas.ac.uk/24894/

Khan, M. (2000). Rents, efficiency and growth. Chapter 1 in Khan, M.H. and

Sundaram, J.K. (eds). Rents, rent-seeking and development: theory and evidence in Asia. Cambridge: CUP.

Kriger, N (2003). Guerrilla veterans in postwar Zimbabwe. Cambridge: CUP.

O’Laughlin, B., Bernstein, H., Cousins, B. and Peters, P. E. (2012). Introduction: agrarian change, rural poverty and land reform in South Africa since 1994. Journal of Agrarian Change, 13(1), 1-15.

Peña, R., Álvarez, R., Ruiz, L. Parada, M., Zuleta, S. (2017). Legal dispossession and civil war in Colombia'. Journal of Agrarian Change, Symposium on Land Rights, Restitution, War and Peace in Colombia

Peters, P.E. (2013). Land appropriation, surplus people and a battle over visions of agrarian futures in Africa. The Journal of Peasant Studies, 40:3, 537-562.

Plümper, T. and Neumayer, E. (2006). The unequal burden of war: the effect of armed conflict on the gender gap in life expectancy. International Organization, $60(3), 723-754$

Ruiz, M. (2016). A bumpy peace for Colombia. New York Times, December $8^{\text {th }}$, http://www.nytimes.com/2016/12/08/opinion/a-bumpy-peace-forcolombia.html? r=0 (accessed December 21 $1^{\text {st }}, 2016$ ). 
This is the accepted version of an article published by Wiley in Journal of Agrarian Change Vol. 17 (4)

October 2017, 733-738. Published version available from:

http://onlinelibrary.wiley.com/doi/10.1111/joac.12239/full

Accepted version downloaded from SOAS Research Online: http://eprints.soas.ac.uk/24894/

Rutherford, B. (2008). Conditional belonging: farm workers and the cultural politics of recognition in Zimbabwe. Development and Change, 39(1), 73-99.

Rutherford, B. (2012). Shifting the debate on land reform, poverty and inequality in Zimbabwe, an engagement with Zimbabwe's land reform: myths and realities 1. Journal of Contemporary African Studies, 30(1), 147-157.

Soifer, H.D. and Vergara, A. eds. forthcoming. Legacies of Conflict: The Effects of the Shining Path conflict on Peruvian Politics. Unpublished book manuscript under advance contract with University of Texas Press.

Starr, E. and Wood, E.J. (2016). The agrarian legacies of Latin American civil wars in comparative perspective. Unpublished paper, Yale University.

Thomas, K.L. and Bond, K.D. (2015). Women's participation in violent political organizations. American Political Science Review, 448-506.

Vargas, J. and Uribe, S. (2017). State, war, and land dispossession: multiple paths to land concentration. Journal of Agrarian Change, Symposium on Land Rights, Restitution, War and Peace in Colombia

Velásquez, M. (2017). Peasant differentiation and service provision in Colombia. Journal of Agrarian Change, Symposium on Land Rights, Restitution, War and Peace in Colombia 
This is the accepted version of an article published by Wiley in Journal of Agrarian Change Vol. 17 (4)

October 2017, 733-738. Published version available from:

http://onlinelibrary.wiley.com/doi/10.1111/joac.12239/full

Accepted version downloaded from SOAS Research Online: http://eprints.soas.ac.uk/24894/

Viterna, J. (2013). Women in war: the micro-processes of mobilization in El

Salvador. New York: OUP.

Wood, E.J. (2003). Insurgent collective action and civil war in El Salvador,

Cambridge: CUP.

Wood, E.J. (2008). The social processes of civil war: the wartime transformation of social networks. Annual Review of Political Science, Vol.11, 539-561.

Woodward, S (2007). Do the root causes of civil wars matter? On using knowledge to improve peacebuilding interventions. Journal of Intervention and Statebuilding 1:2,143-170.

World Bank (2003). Breaking the Conflict Trap: Civil War and Development Policy. Washington, DC: World Bank.

Zetter, R. (2011). Conceptualizing the land-conflict-restitution nexus: the case of Cyprus. Journal of Conflict Transformation and Security, 1 (1), 65-88. 